\title{
Clinical measurement of sagittal trunk curvatures: photographic angles versus rippstein plurimeter angles in healthy school children
}

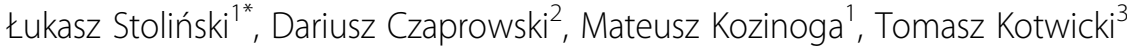 \\ From 11th International Conference on Conservative Management of Spinal Deformities - SOSORT 2014 \\ Annual Meeting \\ Wiesbaden, Germany. 8-10 May 2014
}

\section{Background}

Digital photography is a simply method to calculate quantitative photographic parameters of the body posture in the frontal and sagittal plane.

\section{Aim}

The aim of the study was to determine the correlation between the measurements of the sagittal trunk curvatures carried out with two diagnostic tools: photography and Rippstein plurimeter.

\section{Design}

This is a reliability study.

\section{Methods}

Sixty-one asymptomatic children (31 girls, 30 boys) aged 7-9 years (mean 7.9 \pm 0.8 ) were assessed once by one observer for the sagittal curvatures of the trunk: thoracic kyphosis (TK), lumbar lordosis (LL) and sacral slope (SS) first with digital photography and with Rippstein plurimeter. Statistical analysis was performed using paired Student t-test, Wilcoxon matched-pairs and Pearson correlation coefficient.

\section{Results}

There was no significant difference regarding the measurement of TK performed with photography versus plurimeter $\left(43.3^{\circ} \pm 8.8\right.$ vs. $\left.43.0^{\circ} \pm 8.4, \mathrm{p}=0.47\right)$. Differences were found for LL $\left(39.8^{\circ} \pm 8.2\right.$ vs.38. $\left.3^{\circ} \pm 8.5, \mathrm{p}<0.0001\right)$ and SS $\left(23.3^{\circ} \pm 6.0\right.$ vs. $\left.22.7^{\circ} \pm 6.4, p=0.024\right)$. Significant correlation between measurements performed with photography versus Rippstein plurimeter were observed: TK $(\mathrm{r}=0.949$, $\mathrm{p}<0.0001)$, LL $(\mathrm{r}=0.951, \mathrm{p}<0.0001)$ and SS $(\mathrm{r}=0.944$, $\mathrm{p}<0.0001)$.

\section{Conclusions}

Although significant difference for LL and SS were found, the difference between measurements is small, so it seems that photography and Rippstein plurimeter can be used for assessment of sagittal trunk curvatures in the clinical assessment.

\section{Competing interests}

There was no conflict of interest in relation to this study.

\section{Authors' details}

${ }^{1}$ Rehasport Clinic, Spine Disorders Unit, Department of Pediatric Orthopedics and Traumatology, University of Medical Sciences, Poznań, Poland. 2Department of Physiotherapy, Józef Rusiecki University College, Olsztyn, Poland. ${ }^{3}$ Spine Disorders Unit, Department of Pediatric Orthopedics and Traumatology, University of Medical Sciences, Poznań, Poland.

\section{Published: 4 December 2014}

\section{References}

1. Ferreira EAG, Duarte M, Maldonado EP, Burke TN, Marques AP: Postural assessment software (PAS/SAPO): validation and reliability. Clinics 2010, 65(7):675-81.

2. Stoliński $Ł$, Kotwicki T, Czaprowski D: Active self correction of child's posture assessed with plurimeter and documented with digital photography. Progress in Medicine 2012, 25(6):484-490.

\section{doi:10.1186/1748-7161-9-S1-015}

Cite this article as: Stoliński et al.: Clinical measurement of sagittal trunk curvatures: photographic angles versus rippstein plurimeter angles in healthy school children. Scoliosis 2014 9(Suppl 1):015. 